DOI: $10.14451 / 2.157 .18$

\title{
О ВОЗНИКНОВЕНИИ И РАЗВИТИИ ИНСТИТУТА УГОЛОВНОЙ ОТВЕТСТВЕННОСТИ ЗА НЕЗАКОННЫЙ ВЫВОЗ ВАЛЮТНЫХ ЦЕННОСТЕЙ ЗА РУБЕЖ В ДОРЕВОЛЮЦИОННОЙ РОССИИ
}

\author{
(c) 2021 Жаров Сергей Николаевич \\ профессор кафедры Теории государства и права Института права \\ Челябинский государственный университет, Россия, Челябинск \\ E-mail: serzhar@mail.ru \\ (c) 2021 Бунин Евгений Сергеевич \\ аспирант кафедры уголовного права и криминологии Института права \\ Челябинский государственный университет, Россия, Челябинск \\ E-mail: eugeny.bunin@yandex.ru,
}

\begin{abstract}
Статья посвящена исследованию возникновения и развития уголовной ответственности за незаконный вывоз валютных ценностей за границу. Накопление золота и серебра и монет из этих металлов рассматривалось как обязательный элемент экономического могущества страны. Развитие законодательства показало переход от меркантилистских идей к протекционистским и далее к либерализации таможенной политики, хотя и крайне непоследовательной. Исследование позволило сделать вывод о конкретизации ограничиваемых к вывозу валютных ценностей: сначала это монеты, затем необработанное золото и серебро и изделия из них, а также ценные бумаги. Конкретизируются субъекты правоотношений, вначале купцы, затем вообще все проезжающие, выявляются специальные субъекты: дипломаты, а также банковские служащие и их хозяева. В работе применены диалектический, исторический, сравнительно-правовой, формально-юридический и другие методы.
\end{abstract}

Ключевые слова: история России, таможенная политика, валютные ценности, уголовная ответственность, меркантилизм, протекционизм, незаконный вывоз валюты, оплата агентуры.

В настоящее время совершение международных валютных операций является неотъемлемой частью экономических отношений возникающих между странами-участниками различных экономических союзов, объединений, договоров и соглашений. С возрастающим объемом валютных операций, связанных с экспортно-импортными отношениями, особое место занимает уголовно-правовое регулирование общественных отношений, возникающих при проведении финансовых операций, направленных на покупку/продажу товаров и услуг, предоставляемых нерезидентами, в рамках заключаемых внешнеэкономических контрактов.

Исторически сложившаяся взаимосвязь деятельности органов государственной власти, контролирующих и регулирующих органов, в области законного импорта/экспорта отечественной и иностранной валюты, определяет условия формирования контроля над осуществляемыми финансовыми потоками. Уголовно-правовой институт общественных отношений, возникающих в процессе взаимного развития международных торгово-рыночных и финансово-денежных отношений в его современном виде представлен статьями 193 и 193.1 Уголовного кодекса Российской Федерации. Представляет определенный научный и практический интерес возникновение и развитие института уголовно-правовой ответственности за совершение незаконных валютно-денежных операций направленных на вывод денежных средств за рубеж. В нашем государстве с момента его возникновения этот институт развивался с достаточно хаотичной амплитудой. В связи с принятием крещения Киевской Русью произошли значительные изменения в области становления уголовного законодательства. Развитие внутренних и внешних торгово-рыночных отношений способствовало проникновению новых норм в правовую систему русского государства.

Первые упоминания о зарождающемся институте уголовно-правовых отношений можно обнаружить в Пространной редакции «Русской Правды». Согласно ст. 48 «Аже кто купець купцю дасть в куплю куны или в гостьбу, то купцю пред 
послухи кунъ не имати, послуси ему не надобъ, но ити ему самому роть, аже ся почнеть запирати»*. Содержание статьи указывает на особое правовое регулирование общественных отношений складывающихся между торговцами при передаче денежных средств, для совершения торговых сделок местной и иноземной торговли. Таким образом, в процессе становления и развития государства и права выделялось значимое направление экономических правоотношений, связанных с перемещением капиталов при осуществлении торговли с иноземными государствами.

В ходе дальнейшего изучения источников древнерусского уголовного законодательства установлено, что развитие правового регулирования денежных потоков, и финансовых взаимоотношений касалось только событий, происходящих внутри государства. Псковская и Новгородская судные грамоты, Судебники 1497, 1550, 1589 годов регулировали уголовноправовые отношения, складывающиеся в процессе осуществления уплаты пошлин в казну, правил торговли, наследства, дачу денег в долг под заклад, правил взыскания заемных денежных средств с чужеземцев.

Возрастающая необходимость регулирования денежных потоков не могла быть не отмечена комиссией, избранной земским собором в 1648 году, результатом деятельности которой явилось создание Соборного Уложения 1649 года. Данный правовой акт определил дальнейший путь развития и совершенствования уголовного законодательства в целом. Так, глава VI закрепила положение о проезжих грамотах в иные государства, эти нормы регулировали право торговцам совершать куплю-продажу товаров за пределами российского государства. Таким образом, можно провести аналогию с современными условиями, необходимыми для совершения внешнеэкономических операций по переводу денежных средств на счета нерезидентов, а именно помимо заключения внешнеэкономического контракта необходимо открыть паспорт сделки, являющийся непосредственным основа- нием для осуществления транзакции.

Дальнейшее развитие законодательства о регулировании международных финансовых операций связано с распространением в России идей раннего меркантилизма, одним из проводников которого был глава Посольского приказа боярин А.Л. Ордин-Нащокин. По его инициативе и под его редакцией был создан один из замечательных нормативных правовых актов Московского государства - Новоторговый устав 1667 г.

Важными новеллами устава были серьезные ограничения в торговых делах для иностранных купцов. Во-первых, их торговля была территориально ограничена: только в крупных пограничных городах Новгороде, Пскове, Архангельске, и по специальным разрешениям от русского правительства. Во-вторых, иностранцам запрещены были сделки друг с другом, а также торговля в розницу. В-третьих, сбор с иностранцев устанавливался более чем втрое выше, чем с русских купцов (6\% собственно пошлина и 10\% проезжая, а для русских купцов всего 5\%)**. В-третьих, в уплату пошлин и товар принимались серебряные талеры, если же иностранец привозил не товар, а золотые и серебряные монеты, то получал различные льготы, в том числе освобождение от пошлин. Попытка утаить привезенные деньги могла закончиться крупным штрафом или даже полной конфискацией ${ }^{* * *}$.

Последующие упоминания о конкретных видах ответственности за совершение противоправных действий, связанных с выводом капитала за пределы государственных границ, в нормативно-правовых актах отсутствуют. Запреты на вывоз за границу золота и серебра в монетах и слитках, в изделиях - «в деле и не в деле» - неоднократно повторяются в указах Петра Великого****; однако причина здесь иная, чем в предыдущий период. По мнению К.Н. Лодыженского, протекционизм Петра существенно отличался от меркантилизма его предшественников, и он скорее пользовался средствами, к которым прибегали меркантилисты, чем разделял их принципын****. Что же касается

\footnotetext{
* Российское законодательство Х-ХХ веков. В 9-ти т. Т. 1. М., 1984. С. 67.

** Громыко В.В. Основоположник русского меркантилизма А.Л.Ордин-Нащокин (ок. 1605-1680) // Вестник Российского экономического университета им. Г. В. Плеханова. 2006. № 3. С. 131

*** Российское законодательство Х-ХХ веков. В 9-ти т. Т. 4. М., 1986. С. 128-129.

***** См. ПСЗ РИ. Соб. 1. Т. V. № 3441; Т. VI. № 3748.

***** Лодыженский К. Н. История русского таможенного тарифа. СПб., 1886. С. 56.
} 
санкции за нарушение такого запрета, она была стандартной для множества петровских указов: «под жестоким наказанием заказано».

Определенная либерализация таможенной политики во второй четверти и второй половине XVIII столетия коснулась и такого товара, как драгоценные металлы, но это не было устойчивой тенденцией. К примеру, Екатерина II в своем Наказе (ст. 343) сформулировала идею о возможности перемещения ценностей через границу посредством векселей, и соответственно невозможности запрета на такое перемещение: «после того, как посредством векселей богатства уже больше не принадлежат никакому особливо государству; и когда столь легко можно переносить оныя из одной области в другую; то худым надобно назвать закон недозволяющий располагать о своих землях по собственному всякаго желанию для учреждения дел своих, когда можно располагать о своих деньгах каждому по своей воле»*. Но введенный Екатериной II в 1793 г. таможенный тариф был запретительным, так как призван был сдерживать вывоз из страны золота и серебра**.

Процесс развития российской государственности в первой половине XIX века сопровождался небывалой активностью законотворчества. Данный процесс был обусловлен необходимостью глубокой и качественной систематизации многочисленных и разрозненных нормативноправовых актов царской России. Один из плодов деятельности кодификационных комиссий того периода - проект Уголовного уложения Российской империи 1813 года.

В проекте Уложения 1813 года, в главе 6 «О наказаниях за нарушения особенных государственных прав и принадлежностей», появляется статья, которая непосредственно закрепляет ответственность за совершение вывоза российской монеты за пределы территории государства, который в отделении третьем сформулирован следующим содержанием «О наказании за непозволенный вывоз российской монеты». Статья 251 гласила «Кто из выезжающих из Рос- сии за границу вывозит с собою, вопреки законным постановлениям, российские деньги или непозволенное оных количество, на того, равно и на вспомогателей сего вывоза или обличенных в явном покушении к оному, сверх конфискации вывозимого, налагать денежную пеню против того вдвое». Если данное преступление совершалось повторно, то денежная пеня удваивалась, а если преступление совершалось в третий раз, то помимо взыскания вышеуказанной суммы лицо привлекалось к лишению свободы не менее 3 месяцев и не более двух лет, а также телесно и заключению в рабочие и смирительные дома***.

Однако статьей 253 проекта выделяется особый субъект, а именно дипломатические агенты и прочие представители правительства, для которых привоз или вывоз иностранных денег, золота, серебра и монеты всякого рода регулировался особыми актами правительства. Для дипломатических и разведывательных целей, поддержки агентов влияния в других странах требовались значительные средства. К примеру, руководитель внешнеполитического ведомства Екатерины II граф Н.И.Панин учил своих подчиненных: «Сотрудник иностранной коллегии должен уметь вербовать открытых сторонников и тайных осведомителей, осуществлять подкуп официальных лиц и второстепенных чиновников»****. А высокопоставленные чиновники иностранных государств ценили свои услуги российскому государству весьма недешево. К примеру, французский министр иностранных дел Шарль Морис Талейран в письме Александру I от 15 сентября 1810 г. Прозрачно намекнул, что в последнее время «несколько поиздержался», и просил полтора миллиона франков золо$\mathrm{TOM}^{* * * * * * *}$.

И все же проект Уложения 1813 года не получил законодательного закрепления в качестве нормативно-правового акта, и не вступил в законную силу, однако сформулированные положения статей определили ход развития уголовного законодательства. Характерная для своего времени кодификация и систематизация статей

\footnotetext{
* Наказ Екатерины II Комиссии о составлении проекта нового Уложения. 1767 г. // https://dslov.ru/na/na30.htm (Дата обращения 25 апреля 2021 г.)

*** Муравьева Л.А. Финансовая политика Екатерины II. // Финансы и кредит. 2010 г. № 22(406). С. 80.

*** Безверхов А.Г.Проект Уголовного уложения Российской империи 1813 года: монография. Самара, 2013. С. $109-110$.

**** Очерки истории российской внешней разведки. В 6-ти т. Т. 1. М., 1995. С. 96.

****** Там же. С. 108.
} 
проекта Уложения 1813 года, предопределила дальнейший процесс развития нормотворчества в области уголовного права. И несомненно, что положения данного источника права были использованы при разработке Уложения о наказаниях уголовных и исправительных 1845 года. Вышеуказанные статьи, регулирующие правоотношения, складывавшиеся в процессе ввоза/ вывоза российской монеты, иностранных денег, золота, серебра, стали основой процесса разработки положений регулирующих движение капиталов.

В новом Уложении очень подробно описываются всевозможные составы преступлений и ответственность за их совершение. Объемный и достаточно сложный нормативный правовой акт регулировал различные варианты перемещения валютных ценностей через государственную границу, как законных платежных средств (в монетах и ценных бумагах, отечественных и иностранных), так и фальшивых, и золота в слитках, самородках и шлиховом песке.

В раздел седьмой «О преступлениях и проступках против имущества и доходов казны», главы второй «О нарушении уставов монетных» Уложения 1845 года* включены статьи, в составе которых указана уголовная ответственность за совершение преступлений связанных с внешнеэкономической деятельностью. Смежный с фальшивомонетничеством состав противоправного деяния определен положением статьи 595 Уложения 1845 года, согласно которой «кто заведомо впустит или привезет из-за границы российскую монету, сделанную в чужих краях, тот за сие подвергается наказанию по ст. 588, т.е. ссылкой в каторжные работы на срок от восьми до десяти лет, а также лишением всех прав и состояний, кроме того, провозимая или привезенная монета конфискуется. Однако противоправные действия с использованием атрибутов национальной валюты охранялись государством гораздо жестче, так в статье 597 предусматривалась более лояльная ответственность за незаконный провоз иностранной фальшивой монеты на территорию государства, помимо лишения всех прав и состояний виновный отправлялся в ссылку на каторжные работы на заводы сроком от четырех до шести лет.

Статьи 606 и 610 Уложения 1845 года предполагали аналогичный состав преступления, но уже предметом совершения его выступали поддельные государственные кредитные билеты, билеты государственного казначейства, билеты других кредитных установлений, имеющие в общем обращении достоинство денег, фальшивые иностранные ассигнации и билеты, иностранные кредитные установления. Какие-либо дополнительные составы преступлений, связанные с перемещением денежных средств за пределы государства, в Уложении 1845 года отсутствуют, кроме того, уголовно-правовая ответственность наступала только при перемещении через государственную границу поддельных монет и денег. Таким образом, уголовно-правовые положения совершения межгосударственных валютно-денежных операций как отдельный самостоятельный правовой институт не были законодательно закреплены.

Представляет интерес развитие института уголовной ответственности за незаконный вывоз золота за границу в главе четвертой «За нарушение уставов горных». Ст. 643 Уложения о наказаниях уголовных и исполнительных 1845 года установила таковую ответственность «за вывоз через Азиатскую границу золота как в слитках, так и во всяком другом виде кроме лишь монеты и разных клейменных изделий, парчей, материй, галунов» и пр. предметов в виде наказаний, предусмотренных за кражу, и конфискации вывозимого*. Ответственность лица за совершение данного преступления предусматривалась положениями, охватывающими состав преступления связанного с кражей имущества (ст. 2159), так как предмет преступления являлся товаром при совершении внешнеэкономических сделок, а именно к «лишенію всъхъ особенныхъ, лично и по состоянію присвоенныхъ ему правъ и преимуществъ и ссылкњ на житье въ одну изъ отдален ныхъ губерній, кромъ Сибирскихъ, или, буде онъ по закону не изъятъ отъ наказаній тълесныхъ, отдачъ въ рабочій домъ на время отъ трехъ до шести мъсяцевъ, или же вмъстө того замъняющему сіе заключеніе наказанію розгами». Квалифицирующим признаком было количество вывозимого золота: если его стоимость превышала триста рублей, виновный приговаривался «къ лиіпенію всехъ особенныхъ, лично и по состоянію присвоенныхъ ему правъ и преимуществъ и къ ссылкњ на житье въ губерніи Томскую иди Тобольскую, съ заключеніемъ на время отъ

\footnotetext{
* Свод законов Российской империи. Т. 15. СПб., 1912. С. 74

** Уложение о наказаниях уголовных и исправительных 1845 года. СПб.: В тип. II отд. СЕИВК, 1845. С. 279-280
} 
одного года до двухъ дътъ, или, буде онъ по закону не изъятъ отъ наказаній тълесныхъ, къ наказанію розгами... и къ отдачъ въ исправительныя арестантскія роты гражданскаго вЊдомства на время отъ двухъ до четырехъ льтъ»* .

В редакции Уложения 1885 года (ст. 612) ответственность возникала при вывозе золота не только через азиатскую, но через любую границу: «за всякую без разрешения министра государственных имуществ, продажу, покупку и вывоз за границу золота в песчаном виде или в самородках...» также применялось наказание, предусмотренное за совершение кражи, а в качестве дополнительного - штраф в размере, вдвое превышавшем цену вывозимого золотаж*. По Продолжению 1906 г. наказание устанавливалось в виде тюремного заключения на срок от трех до шести месяцев и конфискации вывозимого драгметалла в казнуж**. Как видим, налицо явная либерализация наказания, связанная, на наш взгляд, с укреплением порядка и дисциплины как на горнодобывающих предприятиях, так и на границе, что сделало подобные преступления редкими и не наносящими существенного ущерба казне.

В главе девять «О нарушении уставов таможенных» регулировались правоотношения, возникавшие при совершении торговли между государствами. Положения статей охватывали уголовно-наказуемые деяния, возникающие в процессе тайного перемещения товаров через государственную границу. Согласно статье 759 «За тайный провоз мимо таможни золотой и банковской серебряной монеты российского чекана в количестве, подлежащем словесному или письменному объявлении, взыскивается: двадцать пять процентов со всей провозимой суммы» ${ }^{* * * * *}$. Кроме того, провозимая из-за границы российская серебряная разменная монета 72 пробы, а также медная монета нового чекана подлежали конфискации, и отсылались на монетный двор для переплавки. В соответствии с примечанием к статье привозить из-за границы российскую разменную медную и серебряную монеты запрещалось. Наказание в виде лише- ния свободы либо ссылки на каторгу за совершение данного преступления не предусматривалось.

22 марта 1903 года императором Николаем II было принято новое Уголовное уложение. Данный нормативно-правовой акт содержал в своем составе общую и особенную части, количество статей сократилось более чем вдвое. Некоторые составы преступлений по объективным признакам были объединены, преступления против казны перестали выделяться как отдельная глава. Сведения о противоправных валютноденежных операциях, связанных с перемещением денежных средств через границу, в данном правовом акте отсутствуют. Однако появляется новый участник производства незаконных финансовых операций, а именно статьей 322 закреплена ответственность содержателя банкирского заведения, меняльной лавки, лица заведующего ими, или состоящих на службе. «..виновный въ производствђ воспрещенной законом или обязательнымъ постановленіемъ сделки наказывается денежною пенею не свыше двух тысяч рублей. Въ случађ повторенія такого проступка виновный наказывается: заключеніемъ въ тюрьмЂ на срокъ не свыше шести мЂсяцевъ и, сверхъ того, денежнымъ взысканіемъ не свыше трехъ тысячъ рублей»*****. Кроме того, данное должностное лицо освобождалось от занимаемой должности и лишалось права содержать банкирское заведение от одного года до пяти лет, а в случае повторного совершения проступка, навсегда. Новый способ совершения преступления с использованием возможностей кредитных и банковских учреждений получил законодательное оформление и заложил дальнейшее развитие составов преступлений, связанных с выводом денежных средств за рубеж.

Таким образом, на протяжении значительного времени мы наблюдаем развитие института уголовной ответственности, за незаконный вывоз валютных ценностей за рубеж, в ходе этого развития сначала регулируется сама возможность такого вывоза, затем вывоз запрещается полностью или частично, либо разрешается

\footnotetext{
* Там же. С. $858-860$

** Уложение о наказаниях уголовных и исправительных 1885 года/ Издано проф. Имп. Училища правоведения... Н. С. Таганцевым. 5-е изд., доп. СПб: тип. М. Стасюлевича, 1886. С. 308.

*** Свод законов Российской империи. Т. 15. СПб., 1912. С. 74

**** Уложение о наказаниях уголовных и исправительных... 1886. С. 321.

****** Новое Уголовное Уложение. СПб.: 1903. С. 113.
} 
определенное количество, либо снимаются все запреты, причем эти запреты достаточно хаотичны. Зато вполне планомерно уточняются предметы преступного вывоза: монеты, необработанные драгоценные металлы, изделия из них, позднее ценные бумаги. На протяжении рассматриваемого периода все более уточняется пере- чень субъектов преступления: если изначально это купцы, в том числе иностранные, то позднее это любые лица, пересекавшие границу, а также владельцы банков и других финансовых учреждений и их служащие, использовавшие для совершения преступления свои служебные полномочия или возможности.

\section{Библиографический список}

1. Безверхов А.Г. Проект Уголовного уложения Российской империи 1813 года: монография / А.Г.Безверхов, В. С. Коростелёв. Самара: Издательство «Самарский университет», 2013. 192 с.

2. Громыко В.В. Основоположник русского меркантилизма А.Л. Ордин-Нащокин (ок. 1605-1680) // Вестник Российского экономического университета им. Г. В.Плеханова. 2006. № 3. С. 128-131.

3. Лодыженский К. Н. История русского таможенного тарифа. СПб.: Тип. В. С. Балашева, 1886. 413 с.

4. Наказ Екатерины II Комиссии о составлении проекта нового Уложения. 1767 г. // https://dslov.ru/na/na30. htm (Дата обращения 25 апреля 2021 г.)

5. Новое Уголовное Уложение. СПб.: Изд. Каменноостровского книжного магазина В. П. Анисимова, 1903.130 c.

6. Муравьева Л. А. Финансовая политика Екатерины II. // Финансы и кредит. 2010 г. № 22(406). С. $72-80$.

7. Очерки истории российской внешней разведки. В 6-ти т. Т. 1. М.: Международные отношения, 1995.240 с.

8. Российское законодательство Х-ХХ веков. В 9-ти т. Т. 1. М.: Юрид. лит., 1984. 432 с.

9. Российское законодательство Х-ХХ веков. В 9-ти т. Т. 4. М.: Юрид. лит., 1986. 512 с.

10. Свод законов Российской империи. Т. 15. СПб., 1912. 202 с.

11. Указ сенатский об осмотре торговых людей, которые поедут за границу, не имеют ли они с собою червонцев, ефимков и серебра, и о даче им из отобранных денег указного числа на проезд. Полное собрание законов Российской империи. Собр. 1. Т. V. № 3441;

12. Указ именной о сложении долгов с денежных дворов; ... о невывозе за границу золота и серебра... Полное собрание законов Российской империи. Собр. 1.T. VI. № 3748.

13. Уложение о наказаниях уголовных и исправительных 1845 года. СПб.: В тип. ІІ отд. СЕИВК, 1845.922 с.

14. Уложение о наказаниях уголовных и исправительных 1885 года/ Издано проф. Имп. Училища правоведения... Н. С. Таганцевым. 5-е изд., доп. СПб: тип. М. Стасюлевича, 1886. 714 с. 